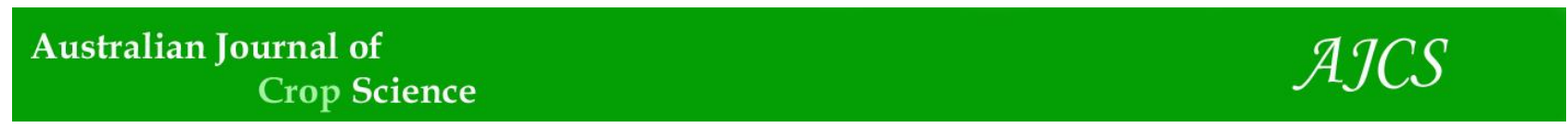

AJCS 15(07):1058-1065 (2021)

ISSN:1835-2707

doi: 10.21475/ajcs.21.15.07.p3175

\title{
The efficiency of Brazilian oat cultivars in reducing fungicide use for greater environmental quality and food safety
}

\author{
Eldair Fabrício Dornelles ${ }^{1}$, José Antonio Gonzalez da Silva ${ }^{1}$, Christiane de Fátima Colet ${ }^{1}$, Denize da Rosa \\ Fraga $^{1}$, Vanessa Pansera ${ }^{1}$, Odenis Alessi ${ }^{1}$, Ivan Ricardo Carvalho ${ }^{1}$, Francine Lautenchleger ${ }^{2}$, Juliana Aozane \\ da Rosa ${ }^{1}$, Eduarda Warmbier ${ }^{1}$, Márcia Sostmeyer Jung ${ }^{1}$, Amanda Klidzio Polanczyk ${ }^{1}$
}

\author{
${ }^{1}$ Regional University of the Northwest of Rio Grande do Sul, ljuí, Brazil. Street of Comércio 3000, \\ Universitário, ljuí/RS, Brazil \\ ${ }^{2}$ State University of Central-West - Street Presidente Zacarias, 875, Guarapuava/PR, Brazil
}

*Corresponding author: carvalho.irc@gmail.com

\begin{abstract}
Oat cultivars more efficient at reducing fungicide can prevent contamination of soil, water and food. The objective of the study is to measure the efficiency of oat cultivars recommended for growing in Brazil by reducing the number of fungicide applications, considering favorable and unfavorable crop season conditions for productivity and progress of the main leaf diseases. The study was conducted in 2015, 2016 and 2017, in Augusto Pestana, RS, Brazil. The experimental design was a randomized block with three replications in a $22 \times 4$ factorial scheme, for 22 oat cultivars and 4 conditions of fungicide use [without application; an application at 60 days after emergence; two applications at 60 and 75 days after emergence; and three applications at 60, 75 and 90 days after emergence]. The fungicide FOLICUR ${ }^{\circledR}$ CE was used in 2015 and 2016 and the fungicide PRIMO ${ }^{\circledR}$ in 2017 in the dosage of 0.75 and 0.3 liters ha-1 ${ }^{-1}$, respectively. The plots were sprayed using BD 04 fan nozzle with 45 PSI pressure, and spray volume close to 120 liters ha1. The condition of a crop season favorable to the progress of leaf diseases identifies with quality cultivars more efficient in reducing the use of fungicide, enabling processes with lower environmental impacts with food security. Under favorable agricultural year conditions and unfavorable to the productivity and progress of the main leaf diseases of oats, the most efficient cultivars to reduce the use of fungicide are URS Altiva and URS Guria.
\end{abstract}

Keywords: Avena sativa, leaf diseases, pesticides, regression, sustainability

Abbreviations: FY_year favorable; UY_year unfavorable; IY_year intermediate; GY_grain yield; NLA_necrotic leaf area; DAE_days after emergence.

\section{Introduction}

Oats are one of the most produced cereals worldwide, mainly for animal feed and human consumption (Pereira et al., 2018; Mantai

et al., 2020). The high nutritional quality of oat grains, combined with the reduction of cholesterol levels in humans, has resulted in a significant increase in consumption of products derived from this cereal (Finnan and Spink, 2016; Mamann et al., 2017). In meeting this demand, the area of oat cultivation has been growing significantly (Romitti et al., 2017; Silva et al., 2020).

Large-scale production makes oat crops susceptible to epidemics, especially to pathogens that cause leaf diseases (Montilla-Bascón et al., 2015; Smulders et al., 2017). Among leaf diseases, fungi that cause leaf rust (Puccinia coronata Cda.f.sp. avenae) and helminthosporiosis [Drechslera avenae (Eidam) El Sharif] receive greater attention (Martinelli et al., 2009; Dietz et al., 2019). These diseases are not satisfactorily controlled by genetic resistance, and the use of fungicide is the most effective form of control (Tormen et al., 2013; Silva et al., 2015; Pereira et al., 2020). The greatest severity of these diseases in southern Brazil is mainly from the flowering phase, due to the increase in temperature and air humidity favorable to fungi, concentrating the greatest use of fungicide in the grain filling phase until near maturation (Nerbass Júnior et al., 2010; Eggers et al., 2020).

Due to the fact that oat grains are used in the production of fresh food, the persistent use of fungicide or applied close to the harvest together with the use of cultivars more dependent on pesticides, increase the risks of contamination of grains and the environment (Oliveira et al., 2015; Mantai et al., 2015). The toxicity of these compounds causes unwanted effects on living beings and the contamination of water, air, soil and food, resulting in damage to the environment and public health (Souza et al., 2015; Lopes and Albuquerque, 2018). Humans stand out in a wide variety of cancer cases, neurological and reproductive problems due to the increased use and consumption of food with pesticide residues (Arcury and Quandt, 1998; Piel et al., 2017).

Reducing the use of pesticides is essential to avoid contamination of food and the environment, due to its cumulative, persistent and toxic action. In this perspective, in the growing of oats it is crucial to develop strategies to ensure greater environmental quality with food security for an increasingly demanding population of healthy products from 
more sustainable technologies. Thus, the objective of the study is to measure the efficiency of oat cultivars recommended for growing in Brazil by reducing the number of fungicide applications, considering favorable and unfavorable crop season conditions for productivity and progress of main leaf diseases.

\section{Results and Discussion}

\section{Classification of agricultural year}

In 2017 (Table 1), air temperature values were higher than in 2015 and 2016 and of strong instability in the vegetative phase. The high temperatures promoted acceleration of the phenological stages, reducing height and cycle. The high temperatures with reduced rainfall and air humidity did not favor the progress of leaf diseases. The reduced soil moisture at the moment of nitrogen application (Figure $1 \mathrm{~A}$ ) promoted less efficiency of nutrient absorption, compromising the productivity expectation of $4000 \mathrm{~kg} \mathrm{ha}^{-1}$ and hindering an analysis more directly linked to the effects of the disease. Under these conditions, the general average grain yield, regardless of the condition of fungicide application, was 1861 $\mathrm{kg} \mathrm{ha}^{-1}$ (Table 1). Therefore, the average productivity values compared to the desired expectation confirm an agricultural year unfavorable to the cultivation (UY) of oats and unfavorable to the progress of leaf diseases (UY).

In 2016 (Table 1), the lowest values of air temperature and with greater stability throughout the cycle were recorded. Rainfall conditions were reduced compared to the historical average, however, with adequate distribution throughout the cycle (Figure 1B). In the grain filling phase, even with more significant rainfall, the mild temperatures hindered the development of leaf diseases. Nitrogen was applied in adequate soil moisture conditions due to rains that occurred in the days before fertilization, favoring the use of the nutrient. According to Table 1, the general average grain yield was $3854 \mathrm{~kg} \mathrm{ha}^{-1}$, close to the desired expectation of $4000 \mathrm{~kg}$ $\mathrm{ha}^{-1}$, a condition that classifies the year 2016 as favorable (FY) to the growing of oats and unfavorable to progress of leaf diseases (UY).

In 2015 , temperatures indicated higher average values and were more unstable compared to 2016. Rainfall was similar to the historical average of the last 25 years, however, with high rainfall during the development cycle. Soil moisture condition was observed in the application of nitrogen by rainfall that occurred in days prior to fertilization. The conditions of high air temperature and volume of rainfall throughout the cycle, conditioning an environment with periods of greater cloudiness and humidity, in 2015 promoted an environment favorable to the development of leaf diseases. This condition is reinforced by the productivity obtained of $2444 \mathrm{~kg} \mathrm{ha}^{-1}$, lower than the expectation, although the conditions of nitrogen application were favorable (Figure 1C). The yield values obtained support the classification of the year 2015 as intermediate (IY) for the growing of oats and favorable to the progress of leaf diseases (FY). It is noteworthy that it represents the year with the possibility of more qualified assessment of the effect of the disease and the characterization of more efficient cultivars to reduce the use of fungicide.

The meteorological elements have a strong influence on the productivity indicators in winter cereals, which require mild temperatures and adequate rainfall distribution (Cordeiro et al., 2015; Trautmann et al., 2020). In the growing of oats, the weather and management conditions have a direct link on the expression of the indicators of productivity and industrial and chemical quality of grains (Nazareno et al., 2017; Mantai et al., 2020). Large volumes or intensity of rain after the supply of nitrogen reduces the efficiency of use by the plant due to the lack of oxygenation and losses by leaching. Elevated temperatures also reduce the efficiency of nutrient use due to losses due to volatilization (Arenhardt et al., 2015; Scremin et al., 2017). Meteorological conditions such as rainfall and air temperature directly influence the severity of leaf diseases (Castro et al., 2012; Silva et al., 2015). Therefore, average temperatures above $20^{\circ} \mathrm{C}$, combined with more frequent rainfall and/or high levels of air humidity, characterize an environment favorable to the development of fungi that cause leaf diseases (Montilla-Bascon et al., 2015; Karise et al., 2016). In oats, the most prevalent and aggressive fungi are leaf rust (Puccinia coronata Cda. F.sp. avenae) and helminthosporiosis [Drechslera avenae (Eidam) El Sharif], causing irreversible damage to the leaf area and to productivity (Nazareno et al., 2017; Dietz et al., 2019).

\section{Linear regression of grain yield and necrotic leaf area}

In Table 2, from the linear regression analysis in the year unfavorable to the growing of oats and progression of leaf diseases (2017), the values of intercept (b0) and slope (b1) for necrotic leaf area showed reduced variability between cultivars. It is noteworthy that the use of the necrotic leaf area through regression analysis, has helped in the study of the genetic resistance of pathogens in different cultures, such as corn (Trojan \& Pria, 2018; Batchelor et al., 2020), soy (Juliatti et al. 2019; Chechi et al., 2021) and oat (Dietz et al. 2019; Lovatto et al. 2021).

Although high levels of necrotic leaf area were observed in the absence of fungicide, the applications of the chemical agent did little to reduce these values. These results show the strong action of weather conditions in the progress of leaf necrosis, mainly due to water restriction and high temperature that occurred during the cycle, impairing the identification of cultivars resistant to fungicide reduction and the longer interval of application to harvest.

The cultivars URS Corona, URS Torena, URS Guria, FAEM 4 Carlasul and IPR Afrodite showed superior angular coefficient of the regression model, in the expression of grain yield, showing greater dependence on the action of the fungicide. On the other hand, cultivars FAEM 007, UPFPS Farroupilha and FAEM 4 Carlasul showed superiority of intercept $\left(b_{0}\right)$, linear coefficient value, indicating less dependence on fungicide applications in a scenario without the use of the product. In this condition, the cultivar FAEM 4 Carlasul shows superiority in the coefficients of linear $\left(b_{0}\right)$ and angular $\left(b_{1}\right)$ regression, capacity for greater productivity without using the fungicide and in response to improved productivity with the number of applications. This genotype seems to indicate a behavior of wide adaptability to the chemical, with the possibility of reducing the agrochemical and with a higher return on productivity compared to the other cultivars.

In Table 3, from the linear regression analysis for the year favorable to the growing of oats and unfavorable to the progress of leaf diseases (2016), the equations obtained for necrotic leaf area also showed reduced variability in the vast majority of cultivars. On the other hand, unlike 2017 (Table 2 ), the values of necrotic leaf area without use of fungicide were very low, indicating the influence of weather conditions on natural disease control, according to the conditions shown in Table 1 and Figure 1. 
Table 1. Temperatures and rainfall in the oat crop cycle and grain yield under conditions of fungicide.

\begin{tabular}{|c|c|c|c|c|c|c|c|c|c|c|c|c|}
\hline \multirow[t]{2}{*}{ Month } & \multicolumn{3}{|c|}{ Temperature ${ }^{\circ} \mathrm{C}$} & \multicolumn{2}{|c|}{ Rainfall (mm) } & \multicolumn{4}{|c|}{ Fungicide/GY $\left(\mathrm{kg} \mathrm{ha}^{-1}\right)$} & \multirow[t]{2}{*}{$\bar{x}$} & \multicolumn{2}{|c|}{ Year Class } \\
\hline & Mín & Máx & Average & 25 years* & Occurred & SF & $\mathrm{CF}_{1}$ & $\mathrm{CF}_{2}$ & $\mathrm{CF}_{3}$ & & Plant & Disease \\
\hline & & & & & \multicolumn{2}{|l|}{2017} & & & & & & \\
\hline May & 14.0 & 22.4 & 18.2 & 149.7 & 434.3 & & & & & & & \\
\hline June & 10.7 & 21.8 & 16.2 & 162.5 & 146.3 & & & & & & & \\
\hline July & 8.3 & 24.4 & 16.3 & 135.1 & 10.75 & \multirow[t]{2}{*}{1149} & \multirow[t]{2}{*}{1869} & \multirow[t]{2}{*}{2116} & \multirow[t]{2}{*}{2310} & \multirow[t]{2}{*}{$1861 \mathrm{C}$} & \multirow[t]{2}{*}{ UY } & \multirow[t]{2}{*}{ UY } \\
\hline August & 11.4 & 23.7 & 17.5 & 138.2 & 117.8 & & & & & & & \\
\hline September & 15.3 & 27.0 & 21.2 & 167.4 & 161.5 & & & & & & & \\
\hline October & 13.7 & 26.8 & 20.2 & 156.5 & 304.0 & & & & & & & \\
\hline \multirow[t]{2}{*}{ Total } & - & - & - & 909 & 1174 & & & & & & & \\
\hline & & & & & \multicolumn{2}{|l|}{2016} & & & & & & \\
\hline May & 11.0 & 20.7 & 15.9 & 149.7 & 55.8 & & & & & & & \\
\hline June & 4.7 & 19.3 & 12.0 & 162.5 & 9.8 & & & & & & & \\
\hline July & 8.5 & 21.5 & 15.0 & 135.1 & 80.5 & \multirow[t]{2}{*}{3200} & \multirow[t]{2}{*}{3814} & \multirow[t]{2}{*}{4072} & \multirow[t]{2}{*}{4331} & \multirow[t]{2}{*}{$3854 \mathrm{~A}$} & \multirow[t]{2}{*}{ FY } & \multirow[t]{2}{*}{ UY } \\
\hline August & 9.4 & 22.5 & 15.9 & 138.2 & 160.0 & & & & & & & \\
\hline September & 8.4 & 22.8 & 15.6 & 167.4 & 56.3 & & & & & & & \\
\hline October & 12.3 & 24.8 & 18.5 & 156.5 & 325.8 & & & & & & & \\
\hline \multirow[t]{2}{*}{ Total } & - & - & - & 909 & 688 & & & & & & & \\
\hline & & & & & \multicolumn{2}{|l|}{2015} & & & & & & \\
\hline May & 13.1 & 22.7 & 17.9 & 149.7 & 181.3 & & & & & & & \\
\hline June & 9.5 & 21.4 & 15.5 & 162.5 & 228.3 & & & & & & & \\
\hline July & 10.5 & 20.6 & 15.5 & 135.1 & 211.5 & \multirow[t]{2}{*}{1229} & \multirow[t]{2}{*}{2086} & \multirow[t]{2}{*}{3055} & \multirow[t]{2}{*}{3406} & \multirow[t]{2}{*}{2444 B } & IY & FY \\
\hline August & 13.3 & 24.8 & 19.0 & 138.2 & 86.8 & & & & & & & \\
\hline September & 12.7 & 20.9 & 16.8 & 167.4 & 127.3 & & & & & & & \\
\hline October & 14.7 & 25.2 & 19.9 & 156.5 & 161.8 & & & & & & & \\
\hline Total & - & - & - & 909 & 997 & & & & & & & \\
\hline
\end{tabular}

Data obtained from the meteorological station located at the Regional Institute for Rural Development (IRDeR/UNIJUÍ) in 2015, 2016 and 2017. FY = favorable year for growing; IY = intermediate year for growing; $\mathrm{UY}=$ unfavorable year for growing; $\mathrm{GY}=$ grain yield; $\mathrm{Min}=$ minimum temperature average; Max = maximum temperature average; ${ }^{*}=$ History of rainfall in the months from May to October of the last 25 years; averages followed by the same letters in the column constitute a statistically homogeneous group using the Skott-Knott model at $5 \%$ probability of error.

A

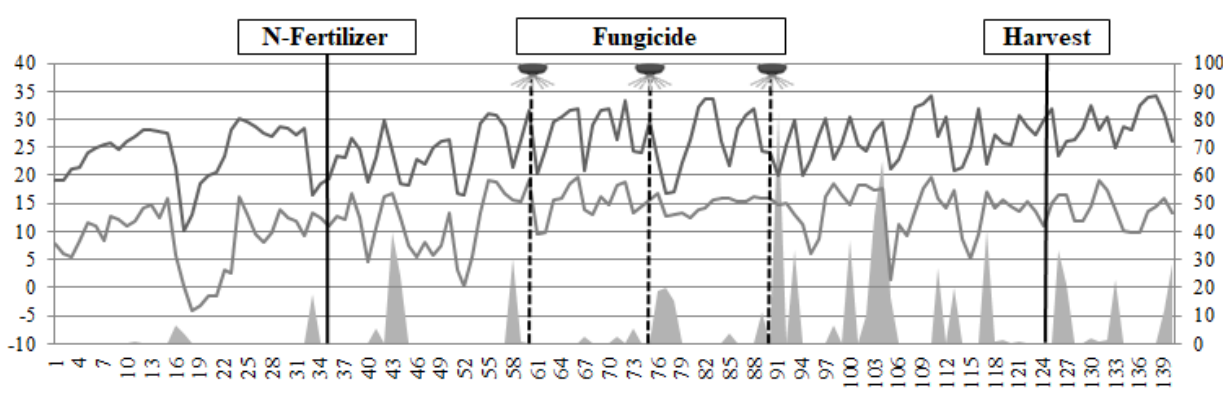

B.

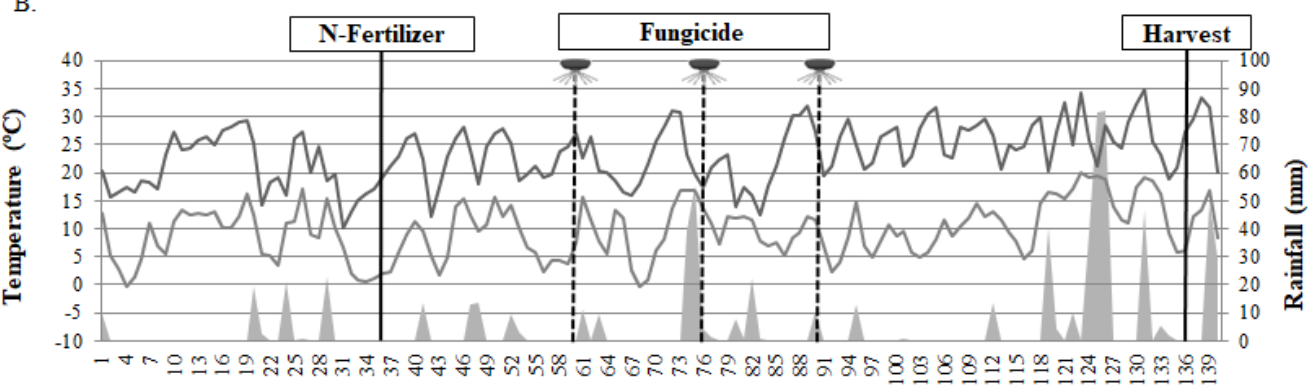

C.

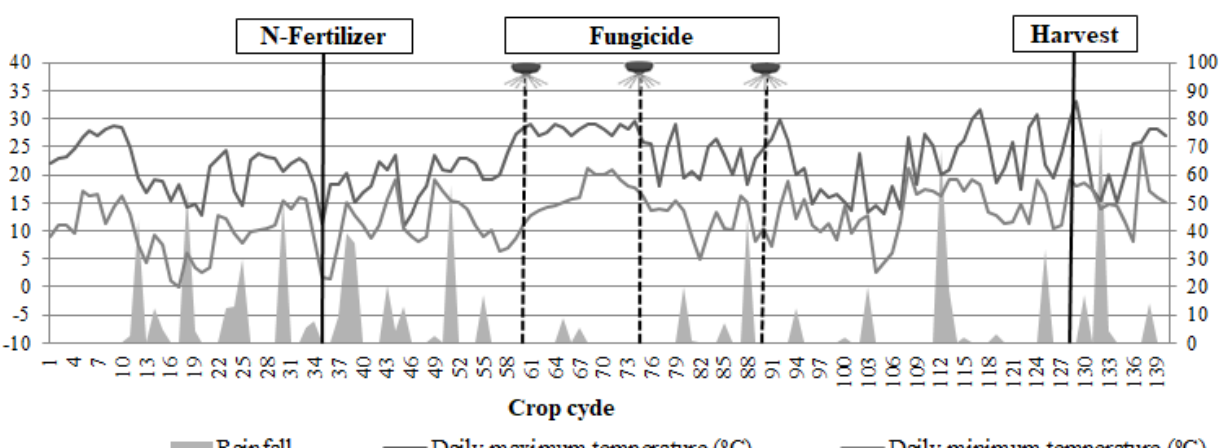

Fig 1. Data of rainfall and minimum and maximum daily temperature during the oat growing cycle: (A) agricultural year 2017, (B) agricultural year 2016 and (C) agricultural year 2015. 
Table 2. Linear regression of grain yield and necrotic leaf area in oat cultivars as a function of the number of fungicide applications in 2017.

\begin{tabular}{|c|c|c|c|c|c|c|}
\hline \multirow[t]{2}{*}{ Cultivar } & \multicolumn{3}{|c|}{ Grain yield (kg ha $\left.{ }^{-1}\right)$} & \multicolumn{3}{|c|}{ NLA105DAE (\%) } \\
\hline & $b_{0} \pm b_{1} x$ & $\mathrm{R}^{2}$ & $P\left(b_{1} x\right)$ & $b_{0} \pm b_{1} x$ & $R^{2}$ & $P\left(b_{1} x\right)$ \\
\hline URS Altiva & $1258+314 x$ & 85 & $*$ & ${ }^{5} 88-12.0 x$ & 70 & $*$ \\
\hline URS Brava & $1211+307 x$ & 85 & $*$ & $92-13.2 x$ & 84 & $*$ \\
\hline URS Guará & $1227+395 x$ & 97 & $*$ & $92-13.8 x$ & 87 & $*$ \\
\hline URS Estampa & $1930+1293 x$ & 87 & $*$ & $93-14.2 x$ & 88 & $*$ \\
\hline URS Corona & $1335+{ }^{5} 459 x$ & 86 & $*$ & ${ }^{5} 88-12.3 x$ & 64 & $*$ \\
\hline URS Torena & $1996+5509 x$ & 93 & $*$ & $92-13.3 x$ & 82 & $*$ \\
\hline URS Charrua & $1127+367 x$ & 86 & $*$ & ${ }^{5} 89-12.8 x$ & 73 & $*$ \\
\hline URS Guria & $1183+{ }^{5} 474 x$ & 99 & $*$ & $92-10.9 x$ & 83 & $*$ \\
\hline URS Tarimba & $1865+397 x$ & 98 & $*$ & $90-{ }^{5} 10.0 x$ & 66 & $*$ \\
\hline URS Taura & $1228+384 x$ & 89 & $*$ & $90-13.6 x$ & 76 & $*$ \\
\hline URS 21 & $1250+342 x$ & 77 & $*$ & $196-12.2 x$ & 94 & $*$ \\
\hline FAEM 007 & ${ }^{s} 1709+324 x$ & 72 & $*$ & $92-10.8 x$ & 80 & $*$ \\
\hline FAEM 006 & $1515+406 x$ & 88 & $*$ & $196-15.6 x$ & 94 & $*$ \\
\hline FAEM 5 Chiarasul & $1480+327 x$ & 93 & $*$ & $90-9.6 x$ & 65 & $*$ \\
\hline FAEM 4 Carlasul & ${ }^{s} 1776+{ }^{s} 499 x$ & 99 & $*$ & $92-17.7 x$ & 90 & $*$ \\
\hline Brisasul & $1180+360 x$ & 88 & $*$ & $90-13.3 x$ & 76 & $*$ \\
\hline Barbarasul & $1339+1222 x$ & 83 & $*$ & $92-13.7 x$ & 84 & $*$ \\
\hline URS Fapa Slava & $1143+451 x$ & 89 & * & $92-11.8 x$ & 83 & * \\
\hline IPR Afrodite & $1344+{ }^{5} 453 x$ & 92 & $*$ & $90-17.2 x$ & 82 & $*$ \\
\hline UPFPS Farroupilha & ${ }^{5} 1714+330 x$ & 71 & $*$ & $92-13.6 x$ & 85 & $*$ \\
\hline UPFA Ouro & $1364+359 x$ & 92 & $*$ & $196-11.7 x$ & 95 & $*$ \\
\hline UPFA Gaudéria & $1465+233 x$ & 78 & $*$ & $93-59.3 x$ & 78 & $*$ \\
\hline Overall mean & $1302+373 x$ & & & $92-12.8 x$ & & \\
\hline Standard deviation & $239+79 x$ & & & $2-2.2 x$ & & \\
\hline Superior (S) & $1541+452 x$ & & & $90-10.7 x$ & & \\
\hline Inferior (I) & $1062+294 x$ & & & $94-15.0 x$ & & \\
\hline
\end{tabular}

$\mathrm{NLA}_{105 D A E}(\%)=$ necrotic leaf area evaluated 105 days after emergence; $\mathrm{P}\left(\mathrm{b}_{1} \mathrm{x}\right)=$ parameter that measures the slope of the line by the probability of $\mathrm{T}$ at $5 \%$ error; $\mathrm{R}^{2}=$ coefficient of determination; $*$ significant at $5 \%$ probability of error; ${ }^{\mathrm{s}}=$ higher than the average plus a standard deviation for the GY variable and lower than the average minus a standard deviation for the variable NLA ${ }_{105 D A E}{ }^{\prime}=$ below the average minus one standard deviation for the GY variable and above the average plus one standard deviation for the variable NLA $A_{105 D A E} ; S D=s t a n d a r d ~ d e v i a t i o n$.

Table 3. Linear regression of grain yield and necrotic leaf area in oat cultivars as a function of the number of fungicide applications in 2016.

\begin{tabular}{|c|c|c|c|c|c|c|}
\hline \multirow[t]{2}{*}{ Cultivar } & \multicolumn{3}{|c|}{ Grain yield (kg ha-1) } & \multicolumn{3}{|c|}{ NLA 105DAE $(\%)$} \\
\hline & $b_{0} \pm b_{1} x$ & $\mathrm{R}^{2}$ & $P\left(b_{1} x\right)$ & $b_{0} \pm b_{1} x$ & $\mathrm{R}^{2}$ & $P\left(b_{1} x\right)$ \\
\hline URS Altiva & $2965+{ }^{5} 567 x$ & 91 & $*$ & $8-2.3 x$ & 92 & $*$ \\
\hline URS Brava & $3393+310 x$ & 93 & $*$ & $8-1.9 x$ & 90 & $*$ \\
\hline URS Guará & $3635+292 x$ & 94 & $*$ & $6-0.7 x$ & 99 & $*$ \\
\hline URS Estampa & $3354+149 x$ & 81 & ns & $12-3.0 x$ & 94 & $*$ \\
\hline URS Corona & ${ }^{s} 4063+393 x$ & 74 & $*$ & $8-2.7 x$ & 90 & $*$ \\
\hline URS Torena & $2922+465 x$ & 99 & $*$ & $3-1.1 x$ & 92 & $*$ \\
\hline URS Charrua & $3711+179 x$ & 75 & ns & $14-{ }^{1} 5.6 x$ & 78 & $*$ \\
\hline URS Guria & $2533+441 x$ & 85 & $*$ & $7-2.7 x$ & 83 & $*$ \\
\hline URS Tarimba & $3412+425 x$ & 98 & $*$ & $' 18-15.6 x$ & 94 & $*$ \\
\hline URS Taura & $2361+{ }^{5} 850 x$ & 98 & $*$ & $11-4.0 x$ & 88 & $*$ \\
\hline URS 21 & $3361+{ }^{\prime} 142 x$ & 93 & ns & $11-4.3 x$ & 85 & $*$ \\
\hline FAEM 007 & $3751+444 x$ & 92 & $*$ & $13-4.1 x$ & 81 & $*$ \\
\hline FAEM 006 & $3489+335 x$ & 85 & $*$ & $' 17-15.8 x$ & 95 & $*$ \\
\hline FAEM 5 Chiarasul & $3209+286 x$ & 77 & $*$ & $4-0.8 x$ & 98 & $*$ \\
\hline FAEM 4 Carlasul & s3889 + '114x & 72 & ns & $3-0.8 x$ & 98 & $*$ \\
\hline Brisasul & $3306+518 x$ & 97 & $*$ & $5-1.3 x$ & 89 & $*$ \\
\hline Barbarasul & $3498+471 x$ & 94 & $*$ & $5-1.2 x$ & 97 & $*$ \\
\hline Fapa Slava & $2438+481 x$ & 73 & $*$ & $' 26-9.9 x$ & 80 & $*$ \\
\hline IPR Afrodite & ${ }^{s} 4117+343 x$ & 96 & $*$ & $5-1.6 x$ & 99 & $*$ \\
\hline UPFPS Farroupilha & $3408+346 x$ & 98 & $*$ & $8-1.6 x$ & 97 & $*$ \\
\hline UPFA Ouro & $2781+300 x$ & 98 & $*$ & $8-2.0 x$ & 85 & $*$ \\
\hline UPFA Gaudéria & $3158+179 x$ & 76 & $*$ & $6-1.7 x$ & 94 & $*$ \\
\hline Overall & $3307+365 x$ & & & $9-2.9 x$ & & \\
\hline SD & $486+169 x$ & & & $6-2.2 x$ & & \\
\hline Superior & $3793+533 x$ & & & $3-0.7 x$ & & \\
\hline Inferior & $2821+196 x$ & & & $15-5.1 x$ & & \\
\hline
\end{tabular}

$\operatorname{NLA}_{105 D A E}(\%)=$ necrotic leaf area evaluated 105 days after emergence; $P\left(b_{1} x\right)=$ parameter that measures the slope of the line by the probability of $T$ at $5 \%$ error; $R^{2}=$ coefficient of determination; $n s$ $=$ not significant at $5 \%$ probability of error; ${ }^{*}=$ significant at $5 \%$ probability of error; ${ }^{\mathrm{S}}=$ higher than the average plus a standard deviation for the GY variable and lower than the average minus a standard deviation for the variable NLA $105 \mathrm{DAE} ;{ }^{\prime}=$ below the average minus one standard deviation for the GY variable and above the average plus one standard deviation for the variable NLA ${ }_{105 D A E}$; SD = standard deviation. 
Table 4. Linear regression of grain yield and necrotic leaf area in oat cultivars as a function of the number of fungicide applications in 2015.

\begin{tabular}{|c|c|c|c|c|c|c|}
\hline \multirow[t]{2}{*}{ Cultivar } & \multicolumn{3}{|c|}{ Grain yield $\left(\mathrm{kg} \mathrm{ha}^{-1}\right)$} & \multicolumn{3}{|l|}{ NLA105DAE $(\%)$} \\
\hline & $b_{0} \pm b_{1} x$ & $\mathrm{R}^{2}$ & $P\left(b_{1} x\right)$ & $b_{0} \pm b_{1} x$ & $\mathrm{R}^{2}$ & $P\left(b_{1} x\right)$ \\
\hline URS Altiva & ${ }^{s} 2204+654 x$ & 98 & $*$ & $60-22.3 x$ & 89 & $*$ \\
\hline URS Brava & $1338+908 x$ & 99 & $*$ & $43-16 x$ & 79 & $*$ \\
\hline URS Guará & $1500+698 x$ & 96 & $*$ & $62-23.9 x$ & 81 & $*$ \\
\hline URS Estampa & $1667+567 x$ & 97 & $*$ & ${ }^{s} 28-{ }^{s} 5.7 x$ & 97 & $*$ \\
\hline URS Corona & $990+838 x$ & 96 & $*$ & '100-'31.0x & 74 & $*$ \\
\hline URS Torena & $1594+1503 x$ & 84 & $*$ & $63-18.2 x$ & 90 & $*$ \\
\hline URS Charrua & ${ }^{\mathrm{s}} 1882+{ }^{\prime} 489 x$ & 82 & $*$ & $54-19.2 x$ & 86 & $*$ \\
\hline URS Guria & ${ }^{\mathrm{s}} 2075+556 x$ & 93 & $*$ & $50-18.8 x$ & 79 & $*$ \\
\hline URS Tarimba & $1264+635 x$ & 95 & $*$ & $49-14.9 x$ & 88 & $*$ \\
\hline URS Taura & $990+607 x$ & 96 & $*$ & $72-25.1 x$ & 77 & $*$ \\
\hline URS 21 & $1650+1553 x$ & 91 & $*$ & $58-19.1 x$ & 84 & $*$ \\
\hline FAEM 007 & $1591+876 x$ & 89 & $*$ & $83-24.0 x$ & 77 & $*$ \\
\hline FAEM 006 & $933+{ }^{5996 x}$ & 96 & $*$ & $188-130.1 x$ & 83 & $*$ \\
\hline FAEM 5 Chiarasul & $581+{ }^{5} 1164 x$ & 93 & $*$ & $190-130.8 x$ & 87 & $*$ \\
\hline FAEM 4 Carlasul & $1451+774 x$ & 92 & $*$ & $63-20.2 x$ & 77 & $*$ \\
\hline Brisasul & $1253+918 x$ & 93 & $*$ & $38-{ }^{s} 10.5 x$ & 83 & $*$ \\
\hline Barbarasul & $1828+{ }^{5} 1090 x$ & 93 & $*$ & $194-131.8 x$ & 86 & $*$ \\
\hline URS Fapa Slava & $1197+729 x$ & 90 & $*$ & $52-11.8 x$ & 92 & $*$ \\
\hline IPR Afrodite & ${ }^{\prime} 611+{ }^{5} 972 x$ & 98 & $*$ & $80-130.2 x$ & 85 & $*$ \\
\hline UPFPS Farroupilha & $1535+719 x$ & 93 & $*$ & $54-20.1 x$ & 89 & $*$ \\
\hline UPFA Ouro & $1490+648 x$ & 98 & $*$ & ${ }^{s} 25-{ }^{s} 9.3 x$ & 76 & $*$ \\
\hline UPFA Gaudéria & $1396+618 x$ & 98 & $*$ & ${ }^{s} 24-s_{5.8 x}$ & 91 & $*$ \\
\hline Overall & $1319+750 x$ & & & $60-19.9 x$ & & \\
\hline SD & $453+194 x$ & & & $22-8.1 x$ & & \\
\hline Superior & $1722+944 x$ & & & $38-11.8 x$ & & \\
\hline Inferior & $866+555 x$ & & & $82-28.0 x$ & & \\
\hline
\end{tabular}

NLA $105 \mathrm{DAE}(\%)=$ necrotic leaf area evaluated 105 days after emergence; $\mathrm{P}\left(\mathrm{b}_{1} \mathrm{x}\right)=$ parameter that measures the slope of the line by the probability of $\mathrm{T}$ at $5 \%$ error; $\mathrm{R}^{2}=$ coefficient of determination; $*=$ significant at $5 \%$ probability of error; ${ }^{\mathrm{S}}=$ higher than the average plus a standard deviation for the GY variable and lower than the average minus a standard deviation for the variable NLA ${ }_{105 D A E}{ }^{\prime}=$ below the average minus one standard deviation for the GY variable and above the average plus one standard deviation for the variable NLA $\mathrm{A}_{105 D \mathrm{AE}} ; \mathrm{SD}=$ standard deviation.

The cultivar FAEM 4 Carlasul (Table 3) also shows superior performance due to the linear regression coefficient in the absence of fungicide and lower in the conditions of greater disease control by the fungicide. The results obtained in 2016 show that the favorable conditions for the growing of oats due to the lower rainfall with adequate distribution, and a milder air temperature throughout the cycle, were decisive to the increase in grain productivity, showing no contribution by the fungicide effect. Fact that justifies that the management of fungicide application must consider the entry of the disease by the characteristic sign and observation of the degree of evolution through the genotype versus environment interaction. It should not be defined for days throughout the cycle or stage of growth of the crop, which may imply unnecessary use of pesticides, causing greater environmental damage. In this year of 2016, the cultivars URS Corona and IPR Afrodite stand out again, presenting superior performance of linear coefficient, with grain yield above the expectation of $4000 \mathrm{~kg} \mathrm{ha}^{-1}$ in the absence of fungicide use. The cultivars URS Altiva and URS Taura showed superiority of angular coefficient, with more effective responses to increase in productivity by the number of applications, characterizing greater dependence by the cumulative number of applications. Highlight for the cultivar URS Taura, showing that with each application of fungicide there is an increase of $850 \mathrm{~kg} \mathrm{ha}^{-1}$ of grain yield, confirming high dependence on the chemical product. This condition was somewhat expected, as it represents the most grown genotype in southern Brazil and more than 10 years of commercial launch and growing. Therefore, the greater dependence on fungicide corroborates the natural selection of breeds of fungi over time, making this cultivar more susceptible to leaf diseases.

In Table 4, year 2015, it was possible to characterize with quality the efficiency of oat cultivars to reduce fungicide and a longer interval from application to harvest, due to conditions favorable to the progress of the main leaf diseases (Table 1, Figure 1).

The cultivar FAEM 006 does not present inferiority of intercept (b0) in the absence of fungicide together with the ability to respond to the use of the chemical agent. The cultivars URS Altiva and URS Guria presented superior intercept performance (b0) in the respective regression equations for grain yield and with a linear increase by the use of fungicide within the general average of expression of the cultivars. In addition, not showing inferiority in the expression of necrotic leaf area, characterizing in this year favorable to the disease, genotypes with greater efficiency in reducing fungicide use (Table 4). It is noteworthy that in the expression of the necrotic leaf area, the cultivars URS Estampa, Brisasul, UPFA Ouro and UPFA Gaudéria showed superior performance due to lesser leaf necrosis, however, they did not show concomitantly superior expression of yield.

It is important to mention that not all cultivars with the largest necrotic leaf area were the ones with the lowest yield, suggesting that the necrotic area can be compensated for by inducing greater photosynthetic efficiency in the area with healthy tissue. This condition strengthens the hypothesis that there are resistance mechanisms not directly linked to the reduction of leaf necrosis, but on the increase in the efficiency of photosynthesis by healthy tissue, compensating for the increase in necrotic tissue. A condition that may enable new strategies for selecting more resistant genotypes, with a view to reducing the use of fungicides and living with the disease, as long as it guarantees satisfactory productivity.

Leaf diseases, when not controlled, result in irreversible losses in the productivity of oat grains. Among leaf diseases, leaf rust and yellow spot are the ones that cause the greatest damage to the crop (Oliveira et al., 2014; Nazareno et al., 
2017). The genetic resistance found in oat cultivars is inefficient and when present it is quickly overcome by the selection pressure in the development of new pathogenic populations, mainly in large-scale growing and several agricultural production crops. Thus, the application of fungicides ends up being the most effective form of control (Montilla-Bascón et al., 2015; Silva et al., 2015). The oat cultivars recommended for growing in Brazil exhibit different behaviors in response to weather conditions and the development of diseases, with the severity of the disease directly linked to the degree of genetic resistance, temperature and air humidity (Marcos et al., 2015; Marolli et al., 2018). Therefore, there is a need for research that constitutes a qualified database of different agricultural years for the analysis of the pathogen-host-atmosphere interaction, the identification of genes of interest and the modeling in disease prediction, seeking more efficient and sustainable control forms. In oats, Mourtzinis, Conley and Gaska (2015) found a significant increase in grain yield through the use of fungicide, without reducing the nutritional quality characteristics of the grains, however, not checking for possible pesticide residues in the grains. Most articles published on the topic 'pesticides' focus on the acute effects and the type of exposure to the chemical. No research was found on the intake of contaminated food and its short and long-term exposure to oats, making it urgent to analyze the exposure and food intake to health problems (Lopes and Albuquerque, 2018). In this context, the use of more resistant or resilient cultivars with managements that provide satisfactory yield centered on sustainability, balancing economic and environmental factors is a way to meet the growing demand for food with food safety (Gonçalves de Campos et al., 2015; German et al., 2017). In this perspective, the reduction in the use of pesticides and the promotion of more sustainable agriculture is essential to reduce the risks and impacts on public health and the environment (Machado et al., 2018). Neto et al. (2019) conducted a study of yield performance and reaction of white oat cultivars to rust and leaf spot, finding acceptable productivity averages in the absence of fungicide. Condition that generates the possibility of adjusting the genotype versus management interaction in the perspective of developing an organic cereal production system. The United Nations Sustainable Development Goals highlight as a major challenge the urgent need to transform agriculture and the food sector to achieve food security with social and environmental sustainability (Dhankher \& Foyer, 2018). Therefore, food security needs to be promoted based on new concepts, which requires a broader and more systemic approach, including the environment, technology, the economy and society, at all levels of the organization (Nüsslein \& Dhankher, 2016).

\section{Materials and Methods}

\section{Crop area description}

The work was developed in 2015, 2016 and 2017, in Augusto Pestana, RS, Brazil $\left(28^{\circ} 26^{\prime} 30\right.$ 'S latitude and $54^{\circ} 00^{\prime} 58^{\prime} \mathrm{W}$ longitude). The soil of the experimental area is classified as typical dystroferric red latosol (Oxisol). The climate of the region, according to Köppen classification, is of humid subtropical type. Before sowing, soil analysis was performed and the following chemical characteristics were identified: $\mathrm{pH}$ $=6.3 ; \mathrm{P}=34.1 \mathrm{mg} \mathrm{dm}^{-3} ; \mathrm{K}=198 \mathrm{mg} \mathrm{dm}^{-3} ; \mathrm{OM}=3.2 \% ; \mathrm{Al}=0$ $\mathrm{cmolc} \mathrm{dm}^{-3} ; \mathrm{Ca}=6.5 \mathrm{cmolc} \mathrm{dm}^{-3}$ and $\mathrm{Mg}=2.5 \mathrm{cmolc} \mathrm{dm}^{-3}$. The experimental plot consisted of 5 lines of $5 \mathrm{~m}$ in length and line spacing of $0.2 \mathrm{~m}$ to compose the experimental unit of $5 \mathrm{~m}^{2}$. The population density used was 400 viable seeds $\mathrm{m}^{-2}$, according to the technical recommendation. To meet the expected grain yield of $4 \mathrm{t} \mathrm{ha}^{-1}, 10 \mathrm{~kg} \mathrm{ha}^{-1}$ of nitrogen was applied to the base, and the remaining for topdressing at the fourth expanded leaf stage. In addition, based on soil $\mathrm{P}$ and $\mathrm{K}$ contents, 45 and $30 \mathrm{~kg} \mathrm{ha}^{-1}$ of $\mathrm{P}_{2} \mathrm{O}_{5}$ and $\mathrm{K}_{2} \mathrm{O}$ were applied at sowing, respectively.

\section{Experimental design}

The experimental design was a randomized complete block with three replications in a $22 \times 4$ factorial scheme for 22 oat cultivars and 4 conditions of fungicide use. The oat cultivars analyzed represent those recommended for growing in Brazil, as follows: URS Altiva, URS Brava, URS Guará, URS Estampa, URS Corona, URS Torena, URS Charrua, URS Guria, URS Tarimba, URS Taura, URS 21, URS Fapa Slava, FAEM 007, FAEM 006, FAEM 5 Chiarasul, FAEM 4 Carlasul, Brisasul, Barbarasul, IPR Afrodite, UPFPS Farroupilha, UPFA Ouro and UPFA Gaudéria. The conditions of fungicide use were: [control (without application); an application 60 Days After Emergence (DAE); two applications at 60 and 75 DAE and; three applications at 60, 75 and 90 DAE]. In the years 2015 and 2016, the fungicide FOLICUR ${ }^{\circledR}$ CE was used in the dosage of 0.75 liters ha-1 (active ingredient: tebuconazole), in the year 2017 the fungicide $\mathrm{PRIMO}^{\circledR}$ was used in the dosage 0.3 liters ha ${ }^{-1}$ (active ingredient: azoxystrobin and cyproconazole). The plots were sprayed using BD 04 fan nozzle with 45 PSI pressure, and spray volume close to 120 liters $\mathrm{ha}^{-1}$. The conditions of fungicide use were proposed in the possibility of analyzing the intervals between harvest and last application of the pesticide (fungicide), considering the protection period of 15 to 20 days after its application, as indicated by the product. It is noteworthy that the application at 90 DAE was defined to ensure a considerable interval between last fungicide application and grain maturity (around 30 days), ensuring no application in full grain filling (Table 2 , $3,4)$.

\section{Data measurement}

In the control of leaf diseases, the fungicide FOLICUR ${ }^{\circledR}$ CE was used in 2015 and 2016 and the fungicide PRIMO ${ }^{\circledR}$ in 2017 in the dosage of 0.75 and 0.3 liters ha $^{-1}$, respectively. In the study, the variables analyzed were necrotic leaf area (NLA, \%) and grain yield (GY, $\left.\mathrm{kg} \mathrm{ha}^{-1}\right)$. In determining the necrotic leaf area, three plants were randomly collected from each plot. The plants were collected at 60, 75, 90 and 105 days after emergence in all cultivars and fungicide use conditions. From each plant collected the three upper leaves were removed to evaluate the leaf area. The leaves were scanned using the leaf area reader and WinDIAS software (Copyright 2012, Delta-T Devices Limited) determining the disease necrosis area over the total leaf area. In the grain yield estimation, the three central lines of each plot were considered, harvested manually at the moment when the grains had moisture around $15 \%$. The plants were tracked with a stationary harvester and directed to the laboratory to correct grain moisture by $13 \%$ and determine the yield converted to $\mathrm{kg} \mathrm{ha}$ 1 .

\section{Statistical analysis}

The data were submitted to analysis of variance to detect the main effects and interaction "cultivars" and "condition of fungicide use". Then, linear regression analysis ( $Y=b_{0} \pm$ $\left.b_{1} x\right)$, was performed, in the dimensioning of the efficiency of 
the cultivars to the reduction of the pesticide, by the value of the linear coefficient = intercept (b0), which indicates the starting point of the variable in the regression and the slope (b1), which determines the rate of growth or reduction of the variable $y$ by the number of applications. Following with the analysis of the regression parameters by the mean more or less a standard deviation, in the indication of superiority or inferiority of the parameters that describe the efficiency of the cultivars in the different conditions of handling with the fungicide. The analyzes were performed with the aid of the GENES software (Quantitative Genetics and Experimental Statistics, version 2015.5.0).

\section{Conclusion}

The estimate of the grain yield rate and necrotic leaf area as a function of the time and number of fungicide applications allows the identification of oat cultivars that are more efficient in reducing the use of pesticides and with a longer interval of application to harvest, with emphasis on URS Altiva and URS Guria.

The condition of an agricultural year favorable to the progress of leaf diseases identifies with quality cultivars more efficient in reducing the use of fungicide, which can enable the positioning of genotypes to commercial crops with lesser impacts on human health and the environment.

\section{Acknowledgements}

The authors would like to thank CNPq, FAPERGS, CAPES and UNIJUI for the contribution of resources destined to the development of this study and for the scholarships for Scientific and Technological Initiation, Technical Support, Graduate Studies and Research Productivity.

\section{References}

Arcury TA, Quandt SA (1998) Chronic agricultural chemical exposure among migrant and seasonal farmworkers. Soc Natur Resour. 11(8): 829-843.

Arenhardt EG, Silva JAG, Gewehr E, Oliveira AC, Binelo MO, Valdiero AC, Gzergorczick ME, Lima ARC (2015) The nitrogen supply in wheat cultivation dependent on weather conditions and succession system in southern Brazil. Afr J Agric Res. 10: 4322-4330.

Batchelor WD, Suresh LM, Zhen, X, Beyene, Y, Wilson, M, Kruseman, G, Prasanna, B (2020) Simulation of maize lethal necrosis (MLN) damage using the CERES-maize model. Agron. 10(5): 710.

Castro GSA, Costa CHM, Neto JF (2012) Ecofisiologia da aveia branca. Sci Agrar Parana. 11: 1-15.

Chechi A, Deuner, CC, Forcelini CA, Boller W (2021) Asian soybean rust control in response to rainfall simulation after fungicide application. Acta Sci. Agron. 43:1-9

Cordeiro, MB, Dallacort R, Freitas PSL, Seabra JS, Santi A, Fenner W (2015) Aptidão agroclimática do trigo para as regiões de Rondonópolis, São José do Rio Claro, São Vicente e Tangará da Serra, Mato Grosso, Brasil. Rev Agroambient On-line. 9: 96-101.

Dhankher OP, Foyer $\mathrm{CH}$ (2018) Climate resilient crops for improving global food security and safety. Plant Cell Environ. 41(5): 877-884.

Dietz JI, Schierenbeck M, Simón MR (2019) Impact of foliar diseases and its interaction with nitrogen fertilization and fungicides mixtures on green leaf area dynamics and yield in oat genotypes with different resistance. Crop Prot. 121: 80-88.

Eggers HS, Júnior FSS, Streck EA, Trevisol MT, De Moura MB, Jost E, Rodrigues FT (2020) Resposta da aplicação de fungicidas no controle da ferrugem asiática na cultura da soja. Braz J Dev. 6(6): 38924-38930.

Finnan JM, Spink J (2016) Identification of yield limiting phenological phases of oats to improve crop management. J Agric Sci. 155: 1-17.

German RN, Thompson CE, Benton TG (2017) Relationships among multiple aspects of agriculture's environmental impact and productivity: a meta-analysis to guide sustainable agriculture. Biol Rev. 92: 716-738.

Gonçalves AC, Mello GJ, Covari L, Carbo L, Silva JL, Senra REF, Coelho M de FB (2015) A agroecologia como ciência mediadora entre a formação do agrônomo e a agricultura sustentável. Interciencia. 40(3): 172-178.

Juliatti, FC, Mesquita, ACO, Teixeira, FG, Beloti, IF, Mota, LCBM, Fonseca, LJ, Sousa LA, Souza MSXA, Silva NS, Morais, TPD (2019). Caracterização de genótipos de soja com resistência parcial à ferrugem da soja. Summa Phytopathol. 45(3): 313-319.

Karise R, Dreyersdorff G, Jahani M, Veromann E, RunnoPaurson E, Kaart T, Smaggh G, Mand M (2016) Reliability of the entomovector technology using Prestop-Mix and Bombus terrestris $L$. as a fungal disease biocontrol method in open field. Sci Rep. 6.

Lopes CVA, Albuquerque GSC (2018) Agrotóxicos e seus impactos na saúde humana e ambiental: uma revisão sistemática. Saúde Debate. 42: 518-534.

Lovatto M, Silva GBPD, Coelho FK, Martinelli JA, Pacheco MT, Federizzi LC, Delatorre CA (2021) Crown rust on oat genotypes with different levels of resistance: damages and losses. Cienc Rural: 51(3).

Machado LS, Rochett FC, Pires GC, Corrêa RS, Oliveira ABA (2018) Alimentos orgânicos e/ou agroecológicos na alimentação escolar em municípios do Rio Grande do Sul, Brasil. Demetr. 13(1): 101-115.

Mamann ATW, Silva JAG, Scremin OB, Mantai RD, Scremin $A H$, Dornelles EF (2017) Nitrogen efficiency in wheat yield through the biopolymer hydrogel. Rev Bras Eng Agr Amb. 21(10): 697-702.

Mantai RD, Silva JAG, Sausen ATZR, Costa JS, Fernandes SB, Ubessi C (2015) A eficiência na produção de biomassa e grãos de aveia pelo uso do nitrogênio. Rev Bras Eng Agr Amb. 19(4): 343-349.

Mantai RD, Silva JAG, Binelo MO, Sausen ATZR, Rossi DS, Corso JS (2020) Nitrogen management in the relationships between oat inflorescence components and productivity. Rev Bras Eng Agr Amb. 24(6): 385-393.

Marcos MF, Jank L, Fernandes CD, Verzignassi JR, Mallmann G, Queiróz CA, Batista MV (2015) Reação à Bipolaris maydis, agente causal da mancha foliar, em híbridos apomíticos de Panicum maximum. Summa Phytopathol. 41: 197-201.

Marolli A, Silva JAG, Sawicki S, Binelo MO, Scremin AH, Reginato DC, Lambrecht D M (2018) A simulação da biomassa de aveia por elementos climáticos, nitrogênio e regulador de crescimento. Arq Bras Med Vet Zoo. 70(2): 535-544.

Martinelli JA, Chaves MS, Federizzi LC, Savi V (2009) Expressão da resistência parcial à ferrugem da folha da aveia presente na linhagem MN841801, no ambiente do Sul do Brasil. Cienc Rural. 39: 1335-1342. 
Montilla-Bascón G, Rubiales D, Altabella T, Prats E (2015) Free polyamine and polyamine regulation during prepenetration and penetration resistance events in oat against crown rust (Puccinia coronata f. sp. avenae). Plant Pathol. 65: 392-401.

Mourtzinis, S., Conley, S. P., \& Gaska, J. M. (2015). Agronomic management and fungicide effects on oat yield and quality. Crop Sci. 55(3), 1290-1294.

Nazareno ES, Li F, Smith M, Park RF, Kianian SF, Figueroa M (2017) Puccinia coronata f. sp. avenae: a threat to global oat production. Mol Plant Pathol. 19(5): 1047-1060.

Nerbass Junior JM, Casa RT, Kuhnem Júnior PR, Gava F, Bogo A (2010) Modelos de pontos críticos para relacionar o rendimento de grãos de aveia branca com a intensidade de doença no patossistema múltiplo ferrugem da folha: helmintosporiose. Cienc Rural. 40(1): 1-6.

Neto SSO, Zeffa DM, Arruda KMA, Riede CR (2019) White oat agronomic performance and cultivar reactions to leaf rust and leaf spot. Agron Sci Biotechnol. 5: 24-31.

Nüsslein K, Dhankher OP (2016) Project management: food security needs social-science input. Nature. 535(7610): 3737.

Oliveira EAP, Zucareli C, Fonseca ICB, Oliveira JC, Barros ASR (2014) Foliar fungicide and environments on the physiological quality of oat seeds. J Seed Sci. 36: 15-24.

Oliveira AGM, Pereira DD, Camargo LCM, Balan MC, Canteri MG, Igarashi S, Saab OJ GA (2015) Dose e taxa de aplicação de fungicida no controle da ferrugem da folha (Puccinia triticina) e da mancha amarela (Pyrenophora tritici repentis) do trigo. Semin Cienc Agrar. 36(1): 17-30.

Pereira LM, Tissot-Squalli ML, Wildner G, Dornelles EF, Heck TG, Silva JAG (2018) Oxidative stress measurements can indicate the best dose and period of nitrogen fertilizer in white oat crop. Int J Dev Res. 8(1): 18468-18474.

Pereira LM, Stumm EMF, Buratti JBL, Silva JAG, Colet CF, Pretto CR (2020) A utilização de fungicida no cultivo de aveia: uma revisão integrativa da literatura. Res Soc Dev. 9(8): e952986181-e952986181.
Piel C, Pouchieu C, Tual S, Migault L, Lemarchand C, Carles C, Woronoff AS (2017) Central nervous system tumors and agricultural exposures in the prospective cohort AGRICAN. Int J Cancer. 9(8): 1771-1782.

Romitti MV, Doronelles EF, Silva JAG, Marolli A, Mantai RD, Scremin $O B$, Arenhardt EG, Brezolin AP, Reginatto DC, Scremin AH, Lima ARC, Silva DR (2017) The sowing density on oat productivity indicators. Afr J Agric Res. 12: 905-9150.

Scremin OB, Silva JAG, Mamann ATW, Marolli A, Mantai RD, Trautamann APB, Kraisig AR, Kruger CAMB, Dornelles EF (2017) Nitrogen and hydrogel combination in oat grains productivity. Int J Dev Res. 7: 13896-13903.

Silva JAG, Wohlenberg MD, Arenhardt EG, Oliveira AC, Mazurkievicz G, Muller M, Arenhardt LG, Binelo MO, Arnold G, Pretto R (2015) Adaptability and stability of yield and industrial grain quality with and without fungicide in Brazilian oat cultivars. Am J Plant Sci. 6: 1560-1569.

Silva JAG, Mamann ATW, Scremin OB, Carvalho IR, Pereira LM, Lima ARC, Lautenchlegere F, Basso NCF, Argenta CV, Berlezi JD, Porazzi FU, Matter EM, Norbert L (2020) Biostimulants in the indicators of yield and industrial and chemical quality of oat grains. J Agric Stud. 8(2): 68-87.

Smulders MJM, Wiel CCMV, Broeck HCV, Meer IMV, IsraelHoevelaken TPM, Timmer RD, Dinner BJ, Braun S, Gilissen LJWJ (2017) Oats in healthy gluten-free and regular diets: A perspective. Food Res Int. 110: 3-10.

Souza TT, Pereira JLAR, Souza TT (2015) Avaliação da produtividade de milho e controle de doenças foliares. Rev Agrogeoambient. 7(3): 31-37.

Tormen NR, Lenz G, Minuzzi SG, Uebel JD, Cezar HS, Balardin RS (2013) Reação de cultivares de trigo à ferrugem da folha e mancha amarela e responsividade a fungicidas. Cienc Rural: 43: 239-246.

Trautamann APB, Silva JAG, Binelo MO, Valdiero AC, Henrichsen L, Basso N (2020) Simulation of wheat yield by nitrogen and nonlinearity of environmental conditions. Rev Bras Eng Agr Amb. 24(1): 44-51.

Trojan, DG, Pria, MD (2018) Validação de escala diagramática para quantificação da severidade da antracnose da folha do milho. Summa Phytopathol. 44(1): 56-64. 